quai động mach chủ. Không ghi nhân trường hợp rò nội mạch nào trong nhóm bệnh nhân nghiên cứu, tỉ lệ liệt tủy là $5,5 \%$, tỉ lệ tai biến mach máu não là $8 \%$ và tỉ lệ suy thận cần chạy thận là $3 \%$. Tử vong sớm là $8 \%$, thời gian nằm viện trung bình là $17,2 \pm 14$ ngày. Các tác giả kết luận phẫu thuật lai điều trị phình quai động mạch chủ có kểt quả ngắn hạn tốt ở nhóm bệnh nhân lớn tuổi, và kết quả sẽ cải thiên khi kinh nghiệm của ê kíp phẫu thuật tăng lên [6].

Qua các nghiên cứu được trích dẫn ở trên, nhận thây kết quả ngắn hạn của chúng tôi tương đồng với các tác giả trên thế giới. Qua đó cho thấy hiệu quả ngắn hạn rất tốt của phương pháp can thiệp nội mạch điều trị bệnh lý phình động mạch chủ, bao gồm các vùng từ động mạch chủ ngực lên, quai động mạch chủ, động mạch chủ ngực xuống.

\section{KẾT LUÂ̂N}

- 72,50\% bênh nhân đặt 1 ống ghép; 27,50\% cần từ 2 đến 3 ống ghép.

- Không có tai biến liên quan cấu trúc ống ghép trong quá trình can thiệp.

- Có 3 trường hợp tử vong sớm $(3,75 \%), 2$ trường hợp chảy máu phải mổ lại $(2,50 \%), 4$ trường hợp nhồi máu não $(5,0 \%)$ và 2 trường hợp suy thận cần chạy thận nhân tạo $(2,50 \%)$. Tî lệ biến chứng sớm của TEVAR trong nhóm bệnh nhân của chúng tôi khá thấp.

- Có 2 trường hợp rò nội mạch loại IA, trong đó 1 trường hợp xử lý tốt trong mổ, 1 trường hợp theo dõi; 1 trường IB được xử lý tốt bằng nong bóng, 3 trường hợp rò nội mạch loại II. - Hai nhóm không có khác biệt về tử vong và tai biến, biến chứng sớm.

\section{TÀI LIÊU THAM KHẢO}

1. Zainab Faiza, Tariq Sharman (2020). Thoracic Aorta Aneurysm. J StatPearls.

2. Raimund Erbel, Victor Aboyans, Catherine Boileau, et al. (2014). 2014 ESC Guidelines on the diagnosis and treatment of aortic diseases: document covering acute and chronic aortic diseases of the thoracic and abdominal aorta of the adult The Task Force for the Diagnosis and Treatment of Aortic Diseases of the European Society of Cardiology (ESC)35(41): 2873-2926.

3. Jean-Marc Alsac, Ilya Khantalin, Pierre Julia, et al. (2011). The significance of endoleaks in thoracic endovascular aneurysm repair. J Annals of vascular surgery, 25(3): 345-351.

4. Jose P Morales, Roy K Greenberg, Qingsheng Lu, et al. (2008). Endoleaks following endovascular repair of thoracic aortic aneurysm: etiology and outcomes. J Journal of Endovascular Therapy, 15(6): 631-638.

5. Ourania Preventza, Grayson H Wheatley III, Venkatesh G Ramaiah, et al. (2008). Management of endoleaks associated with endovascular treatment of descending thoracic aortic diseases. J Journal of vascular surgery, 48(1): 69-73.

6. Prashanth Vallabhajosyula, Wilson Szeto, Nimesh Desai, et al. (2013). Type I and type II hybrid aortic arch replacement: postoperative and mid-term outcome analysis. J Annals of cardiothoracic surgery, 2(3): 280.

7. Nikolaos Konstantinou, Eike $\mathbf{S}$ Debus, Christine FW Vermeulen, et al. (2019). Cervical debranching in the endovascular era: a single centre experience. J European Journal of Vascular Endovascular Surgery, 58(1): 34-40.

\title{
VIÊM ĐộNG MẠCH CẢNH: CHẨN ĐOÁN, Đİ̂̉U TRI VÀ NHÌN LẠI Y VĂN
}

\author{
Đoàn Quốc Hưng*, Nguyễn Việt Anh*, Nguyễn Sỹ Lánh**
}

\section{TÓM TẮT}

Viêm động mạch cảnh là một hội chứng hiếm gặp và vẫn chửa được hiểu rõ bao gồm đau thường xuất hiện một bên cổ, khối kèm tăng nhận cảm đau vị trí chạc ba động mạch cảnh. Căn nguyên của bệnh vẫn chưa được biết đển, việc chẩn đoán và điều trị bệnh còn nhiều tranh cãi. Chúng tôi báo cáo trường hợp bệnh nhân nam, 39 tuổi, biểu hiện khối vùng cô phải,

*Bệnh viện Hữu Nghị Việt Đức

Chịu trách nhiệm chính: Đoàn Quốc Hưng

Email: hung.doanquoc@gmail.com

Ngày nhận bài: 3/5/2021

Ngày phản biện khoa học: 2/6/2021

Ngày duyệt bài: 16/6/2021 đau nhiêu. Trên các thăm dò chẩn đoán hình ảnh có hình ảnh khối udày không đồng tâm bao bọc chạc ba động mach cảnh phải nhưng không gây hẹp lòng mạch. Chẩn đoán trước mổ là u tiểu thể cảnh, tuy nhiên chẩn đoán xác định sau cùng là viêm động mạch cảnh dạng giả u. Bệnh nhân được phẫu thuật cắt toàn bộ khối giả u chạc ba động mạch cảnh, tái lập tuần hoàn bằngbắc cầu động mạch cảnh chungđộng mach cảnh trong. Sau mổ diễn biến ổn đinh,các triệu chứng lâm sàng cải thiện, không có biến chứng.

Tư khóa: Viêm động mạch cảnh, khối vùng cổ, giả u động mạch cảnh.

\section{SUMMARY \\ CAROTIDYNIA: DIAGNOSIS, TREATMENT AND LITERATURE REVIEW}


Carotidyniais a rare and poorly understood syndrome consisting of unilateral neck pain, swelling and tenderness over the accepted carotid bifurcation. The aetiology of carotidynia is unknown, diagnosis and treatment are the subject of much controversy. We report the case of aman, 39 years old, presenting with a right neck mass, seriouspain. Imaging test revealed fusiform eccentricthickening of the ipsilateral carotid bifurcation without vessel narrowing. The patient was diagnosed with carotid body tumor, but the post-operative diagnosis was carotidynia. The patient was treated surgically at Viet Duc Hospital in $3 / 2021$, with removing the entire carotid bifurcation pseudotumor, vascular reconstruction by common carotid artery-internal carotid artery bypass. The patient was stable and clinical symptoms improved after surgery, there were no complication.

Keywords: Carotidynia, neck mass, carotid pseudotumor.

\section{I. ĐẶT VẤN ĐỀ}

Viêm mạch là bệnh lý viêm các mạch máu, thường dẫn tới thiếu máu, hoại tử và tổn thương viêm ở các cơ quan. Viêm mạch có thể xuất hiện ở bất kỳ mạch máu nào: các động mạch, tiểu động mạch, tĩnh mạch, tiểu tĩnh mạch hoặc các mao mạch. Biểu hiện lâm sàng của viêm mạch rất đa dạng, phụ thuộc vào kích thước và vị trí của các mach bị tổn thương, các cơ quan bị ảnh hưởng, mức độ và loại tổn thương viêm. Có thể viêm từng phần hoặc toàn bộ mạch máu. Tại các vị trí viêm, tình trạng xâm nhập tế bào viêm, hoại tử hoặc sẹo hóa rất khác nhau, xảy ra tại một hoăc nhiều lớp của thành mạch. Viêm động mạch lớn có xu hướng phá hủy lớp nội mạc đàn hồi, bệnh lý gây viêm mạch máu lớn thường gặp gồm bệnh Behcet, viêm mạch tế bào khổng lî̀ và viêm động mạch Takayasu [1]...Viêm động mạch cảnh (Carotidynia) là tổn thương rất hiếm gặp, được mô tả lần đầu tiên bởi tác giả Fay năm 1927, là tình trạng đau không đặc hiệu vùng đầu cổ do tổn thương tại chạc ba động mạch cảnh[2]. Tổn thương chạc ba chủ yếu là sự dày lên không đồng tâm của mô xung quanh thành động mạch do tình trạng viêm mạn tính và không gẩy ảnh hưởng đến huyết động, có thể biểu hiện lâm sàng dưới dạng u (viêm giả u inflammatory pseudotumor). Bênh cần chẩn đoán phân biệt với các bệnh lý khác có tổn thương tại chạc ba động mạch cảnh như u tiểu thể cảnh, phình mạch cảnh, viêm mạch tế bào khổng lồ, lóc động mạch cảnh cũng như giả phình mạch cảnh do chẩn thương [3].

Trong báo cáo này, chúng tôi trình bày trường hợp bệnh nhân chẩn đoán trước mổ là u tiểu thể cảnh, nhưng chẩn đoán sau mổ là bệnh viêm động mạchcảnh dạng giả u, từ đó đối chiếu lại y văn về chẩn đoán và điều trị bệnh viêm động mạch cảnh.

\section{II. ĐỐI TƯƠ'NG VÀ PHƯƠNG PHÁP NGHIÊN CỨU}

1.Đối tượng nghiên cứu: Bệnh nhân điều trị tại trung tẩm tim mạch bệnh viện HN Việt Đức 3/2021; chẩn đoán trước mổ là u tiểu thể cảnh, phẫu thuật cắt u và mạch máu, tái lập tuần hoàn động mạch cảnh trong bằng mach nhân tạo. Chẩn đoán mô bệnh học sau mổ là viêm động mach cảnh

2.Phương pháp nghiên cứu: Mô tả trường hợp lâm sàng, liệt kê lý do vào viện, dấu hiệu lâm sàng, cận lâm sàng, chẩn đoán trước, trong và sau mố; phân tích lý do chẩn đoán không đúng trước mổ, đánh giá phương pháp xử lý trong mổ, kết quả sau mổ; đối chiếu với y văn để rút kinh nghiệm và đóng gópcho chẩn đoán và điều trị bệnh lý hiếm này.

\section{KẾT QUẢ NGHIÊN CứU}

Bệnh nhân nam, 39 tuổi, nghề nghiệp công nhân, thường trú tại Sóc Sơn, Hà Nội. Bệnh nhân không có tiền sử chấn thương vùng cổ, không có tiền sử bệnh lý khác. Phát hiện khối vùng cổ phải cách 1 tháng, to dần, sưng, đau nhiều, không sốt, kèm theo đau đầu nhẹ. Bênh nhân khám tại bệnh viện Ung bướu Hà Nội với chẩn đoán u vùng cổ, siêu âm, chụp MRI cho thấy hình ảnh khối vùng góc hàm phải kích thước $44 \times 28 \mathrm{~mm}$ nằm ở vị trí động mạch cảnh gốc chia ra động mạch cảnh trong ngoài, tổn thương dạng thâm nhiễm ôm quanh bó mạch cảnh, ngấm thuốc mạnh sau tiêm, cần phân biệt giữa tổn thương $\mathrm{u}$ hạch và u cuộn cảnh (hình 1 ). Bệnh nhân được sinh thiết với kết quả là khối giàu tế bào lympho. Bệnh nhân được hội chẩn và nhập viện Hữu nghị Việt Đức với chẩn đoán theo dõi u cuộn cảnh góc hàm phải.
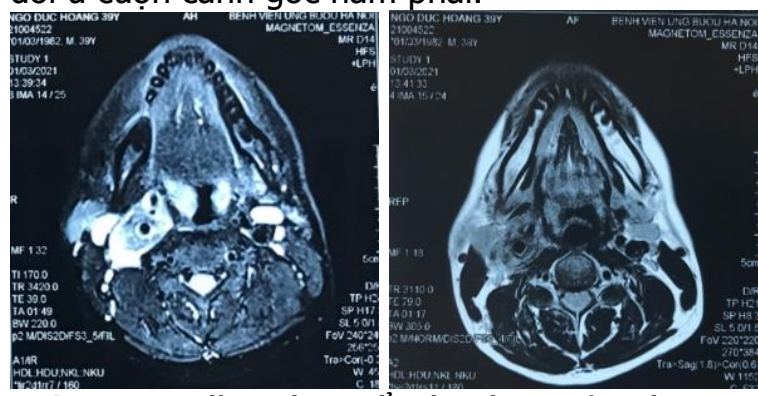

Hình 1. Khối u vùng cổ góc hàm phải trên phim cộng hưởng từ (MRI)

Bệnh nhân nhập viện Hữu nghị Việt Đức ngày 03/3/2021, khám lâm sàng ban đầu phát hiện khối vùng cổ, sát góc hàm phải kích thước khoảng $3 \times 4 \mathrm{~cm}$, chắc, không đập, ấn đau, đau 
tăng khi nhai, nuốt, mạch tứ chi bắt rõ, không có yếu liệt khu trú. Bệnh nhân được làm lại siêu âm vùng cổ cho kết quả động mạch cảnh chung bên phải thành đều nhẵn, không có mảng xơ vữa, phổ doppler trong giới hạn bình thường, động mạch cảnh trong phải không có xơ vữa và huyết khối, không có hẹp lòng mạch, khối giảm âm ôm quanh động mạch cảnh trong kích thước $33 \times 22 \mathrm{~mm}$. Chụp cắt lớp vi tính đa dãy vùng cổ có tiêm thuốc (MSCT) cho thấy nằm ở vị trí góc hàm phải có khối tỳ trọng tổ chức kích thước $41 \times 30 \times 31 \mathrm{~mm}$, ranh giới rõ, ngấm thuốc sau tiêm, khối ôm quanh đoạn phình cảnh và đoạn đầu động mạch cảnh trong bên phải nhưng không thấy xẩm lấn hay hẹp lòng mạch, không thây dấu hiệu đẩy roãng chạc ba động mạch cảnh; bất sản nhánh A1 động mạch não trước và thiểu sản động mạch thông sau bên phải (hình 2). Các kết quả xét nghiệm huyết học, bạch cầu, máu lắng, đông máu, sinh hóa và miển dịch đều trong giới han bình thường.
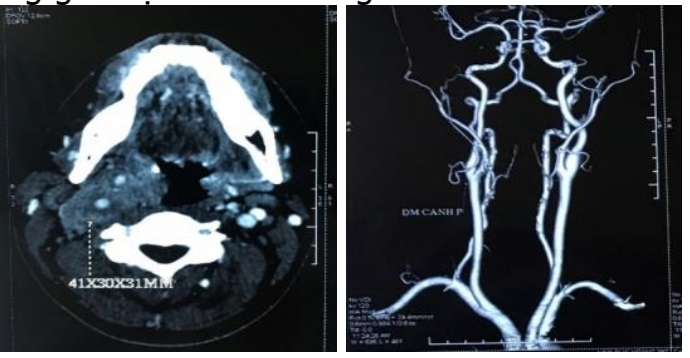

Hình 2. Khối u góc hàm phải trên phim MSCT bao boc xung quanh chạc ba động mạch cảnh phải (ảnh trái) nhưng không ảnh hưởng tới tuần hoàn mach cảnh (ảnh phải)

Ngày 08/3/2021, bệnh nhân được hội chẩn lại với chuyên khoa chẩn đoán hình ảnh để đánh giá lại khối u và xét nút mạch trước mổ, kết luận khối u dạng u tiểu thể cảnh phải type III Shamblin, khối u ôm 1 phần động mạch cảnh chung, lan lên động mạch cảnh trong -cảnh ngoài trên đoạn dài $50 \mathrm{~mm}$. Bệnh nhân được chỉ định nút mạch trước mổ 24 giờ, kết quả chụp mạch không có tăng sinh mạch máu nên không tiến hành nút mạch. Bệnh nhân tiếp tục được hội chẩn với chuyên khoa phẫu thuât tạo hình hàm mă̆t xét mổ phối hợp cắt xương hàm khi cần thiết trong mổ. Bệnh nhân đã được phẫu thuật cắt toàn bộ khối u vào ngày $09 / 3 / 2021$. Quá trình trong mổ, u vị trí chạc ba động mạch cảnh chung, cảnh trong - ngoài, ôm quanh chạc ba và quanh thần kinh $X, X I I$. Gõ dính và giải phóng toàn bộ khối $u$, bảo tồn thần kinh, $u$ xâm lấn không có khả năng bóc tách khỏi thành mạch nên tiến hành cắt toàn bộ u kèm đoạn động mạch cảnh chung-trong-ngoài, làm cầu nối động mạch cảnh chung-động mạch cảnh trong bằng mạch nhân tạo, thắt động mạch cảnh ngoài do tổn thương xân lấn tới chỗ chia ra động mạch mặt (hình 3). Khối u được gửi giải phẫu bệnh. Sau mổ, bệnh nhân diễn biến ổn định, nói nuốt tốt, không có yếu liệt người. Kết quả chụp lại MSCT dựng hình mạch cho thấy cầu nối thông tốt (hình 3).
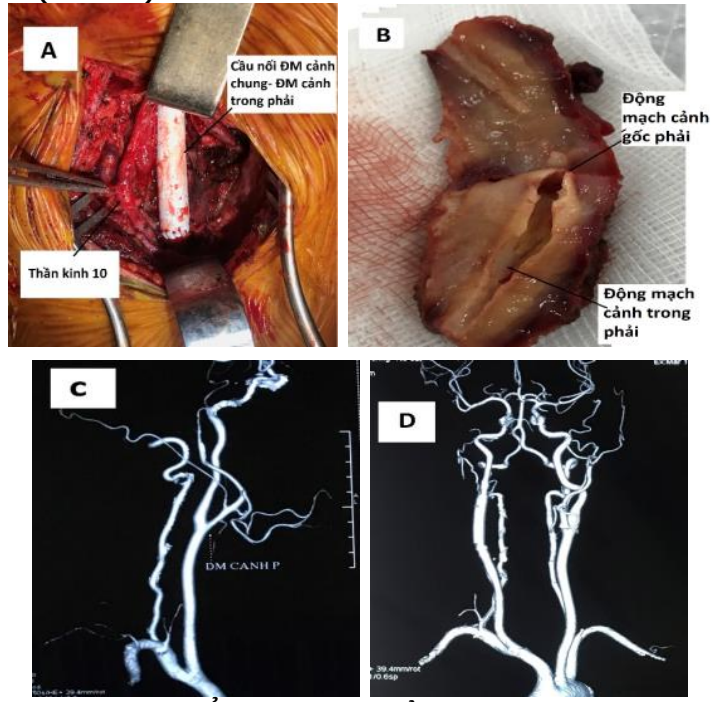

Hình 3. A: Anh trong mồ cầu nổi đông mạch cảnh chung-cảnh trong; B: Đại thể u boc quanh ĐM cảnh; C: MSCT ĐM cảnh phải trước mổ; D: ĐM cảnh phải kiểm tra sau mổ

Giải phẫu bệnh (GPB) cho kêt quả viêm mạch mạn tính với hình ảnh viêm mạch xuyên thành, chủ yếu xâm nhập các tế bào viêm hạt mạn tính, giàu lympho bào, bạch cầu đa nhân, đại thực bào và rải rác tế bào khổng lồ, xơ viêm lan tóa tổ chức mô liên kết xung quanh tạo thành khối giả u (hình 4). Bệnh nhân được làm thêm các xét nghiệm huyết thanh xoắn khuẩn và các kháng thể kháng nhân, kết quả âm tính với xoắn khuẩn giang mai và các kháng thể kháng nhân âm tính. Bệnh nhân ra viện sau 8 ngày kể từ ngày phẫu thuật.

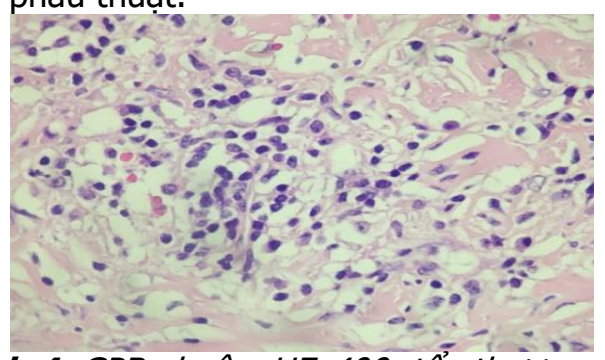

Hình 4. GPB nhuộm HEx400: tốn thương viêm hạt ở lớp áo ngoài, xâm nhập bạch cầu đa nhân trung tính, lymphô bào, tương bào, đại thực bào 


\section{BÀN LUÂN}

Viêm động mạch cảnh là một hội chứng lâm sàng được mô tả với tình trạng đau xuất hiện ở vùng bó mạch cảnh, tăng lên khi nuốt hoặc nhai. Tuổi trung bình phát hiện bệnh là 37 tuổi, hầu hết các ca bệnh tổn thương ở 1 bên, nhưng có khoảng $10 \%$ tổn thương cả 2 bên của mạch cảnh. Các tiêu chí chẩn đoán bệnh được hiệp hội về đau vùng đầu cổ mô tả năm 1994 gồm [4]:

Có ít nhất 1 trong 3 biểu hiện ở động mạch cảnh: Nhạy cảm đau, khối sưng lênhoặc tằng xung động.

- Thăm dò không có bất thường về cấu trúc mạch máu (thành mạch, lòng mạch, huyết động).

- Đau 1 bên cổ có thể ảnh hưởng lên đâu cùng bên.

- Các triệu chứng tự thuyên giảm trong 2 tuần.

Chẩn đoán hình ảnh đóng vai trò quan trọng trong chẩn đoán cũng như gợi ý phân biệt với các bệnh lý khác có tổn thương của mạch cảnh như lóc động mach, phình mach cảnh, xơ vữa động mạch, u tiểu thể cảnh [5]. Trên các thăm dò chẩn đoán hình ảnh thường thấy hình ảnh dày lên và phình to không đồng tâm của tổ chức xung quanh động mạch, không phát hiện được bất kỳ thay đổi về mặt huyết động nào trên siểu âm doppler và trên phim cắt lớp vi tính hoặc cộng hưởng từ không có thay đổi về khẩu kính lòng mạch như hẹp, tắc. Hình ảnh viêm động mạch cảnh trên phim cộng hưởng từ tăng ngấm thuốc ở thì $T 1$ và dày lên của tổ chức xung quanh phần xa của động mạch cảnh chung lan lên chạc ba động mạch cảnh do tình trạng viêm gây nển. Trên phim cộng hưởng từ có tiêm thuốc là hình ảnh tăng ngấm thuốc ở tổ chức viêm xung quanh chạc ba động mạch cảnh [5]. Ngoài cộng hưởng từ, chụp cắt lớp vi tính có sử dụng đồng vị phóng xạ Positron được sử dụng ở một số ít nghiên cứu cho thấy hình ảnh tăng chuyển hóa đường ở tổ chức dày lên xung quanh chac ba động mạch cảnh nhưng không đặc hiệu cho tổn thương u hay viêm. Về mô bệnh học, trên hình ảnh giải phẫu bệnh cho thấy hình ảnh viêm không đặc hiệu với thâm nhập nhiều tế bào lympho và bạch cẩu ở tổ chức viêm bao quanh chạc ba động mạch cảnh, ít thây tế bào tế bào không lồ và tổ chức u hạt hay hoại tử [3].

Với bệnh viêm động mạch cảnh, việc điều trị còn chưa có những hướng dẫn thống nhất nhưng theo nhiều nghiên cứu và báo cáo các trường hợp lâm sàng đơn lẻ, việc điều trị bệnh lý viêm động mạch cảnh thường bắt đầu với thuốc chống viêm không steroid, aspirin hoặc corticoid với liều lượng khác nhau. Theo nghiển cứu của
Augustin Lecler và cộng sự khi tiến hành hồi cứu hệ thống lại các nghiên cứu trước đây về biểu hiện lâm sàng và chẩn đoán hình ảnh trong bệnh lý viêm động mạch cảnh, nghiên cứu lấy số liệu từ 10 nghiên cứu lớn lựa chọn ra được 47 bệnh nhân phù hợp với chẩn đoán viêm động mạch cảnh [6]. Theo nghiên cứu này, tất cả các bệnh nhân đều khởi phát bệnh với triệu chứng đau tại chạc ba động mạch cảnh, gồm 45 bệnh nhân đau 1 bên và 2 bệnh nhân đau cả 2 bên; kết quả chẩn đoán hình ảnh tất cả các bệnh nhân đều có viêm thâm nhiễm quanh chạc ba, với kích thước khối viêm trung bình từ $15-28 \mathrm{~mm}$, và hầu hết không có tổn thương hẹp lòng mạch cảnh cũng như thay đổi huyết động trên siêu âm doppler. Cộng hưởng từ có giá trị đánh giá tốt nhất tình trạng viêm thâm nhiễm quanh thành mạch và kểt quả cộng hưởng từ cũng cho hình ảnh tương tự với tăng tín hiệu tổ chức viêm quanh mạch ở thì T1. Cũng theo nghiên cứu này, hầu hểt các bệnh nhân đều thuyên giảm triệu chứng sau 2 tuần gồm 34 bệnh nhân được điêu trị bằng kháng viêm và aspirin liều cao, 3 bệnh nhẩn điều trị bằng corticoid và 10 bệnh nhân không điều trị gì, mức độ và thời gian thuyên giảm tỷ lệ nghịch với độ dày của tổ chức viêm thâm nhiễm quanh thành mạc [6]. Tham khảo một số nghiên cứu khác thì lại có $x u$ hướng ưu tiên sử dụng corticoid như là thuốc đầu tay điều trị viêm động mạch cảnh với liều khởi đầu là $60 \mathrm{mg} / \mathrm{ngày}$, sau giảm liều xuống $10-20 \mathrm{mg} / \mathrm{ngày}$ dùng trong 4 tuân tiếp theo, thậm chí dài hơn [6]

ở trường hợp của chúng tôi, bệnh nhân phát hiện khối vùng cổ phải- góc hàm phải, to dần, sưng, đau nhiêu. Siêu âm vùng cổ cho kết quả động mạch cảnh chung bên phải phổ doppler trong giới hạn bình thường, động mạch cảnh trong phải không có xơ vữa và huyết khối, không có hẹp lòng mạch, khối giảm âm ôm quanh động mach cảnh.Trền phim chẩn đoán cắt lớp vi tính 64 dãy có tiêm thuốc gợi ý một hình thái của u tiểu thể cảnh type III, dạng u của tế bào tiểu thể cảnh tổn thương ôm quanh từ động mạch cảnh gốc lên đông mạch cảnh trong ngoài (hình 5) [7],tuy nhiên rất ít tăng sinh mạch máu trong khối u, không có hình ảnh đẩy roãng chạc ba mạch cảnh kinh điển, cũng như không có hình ảnh hẹp khẩu kính động mạch cảnh chung, động mạch cảnh trong - ngoài. Trên phim cộng hưởng từ chụp tại bệnh viện ung bướu Hà Nội là một hình tổn thương dạng thâm nhiễm ôm quanh bó mạch cảnh, ngấm thuốc sau tiêm, không có hẹp khẩu kính lòng mạch, cần phân biệt giữa tổn thương $u$ hạch và u cuộn cảnh. $U$ tiểu thể cảnh 
là một trong các khối u phổ biến nhất ở vị trí chạc ba động mạch cảnh trong-ngoài [7],[8] chính vì vậy, với tổn thương u ở vị trí này, chúng tôi hướng đến chẩn đoán u tiểu thể cảnh - phù hợp với tổn thương thường gặp hơn của chạc ba cảnh chung. Tuy về mặt chẩn đoán hình ảnh có một số điểm không hợp lý với u tiểu thể cảnh như: Ít có tăng sinh mạch nuôi u, không có hình ảnh roãng rộng của chạc ba động mach cảnh điển hình trên phim cắt lớp vi tính; cũng như không có tăng sinh xơ viêm tăng tín hiệu và ngấm thuốc trên phim cộng hưởng từ. Trong khi kết quả sinh thiết trước mổ cũng cho kết quả khối giàu tế bào lympho, không đặc hiệu.
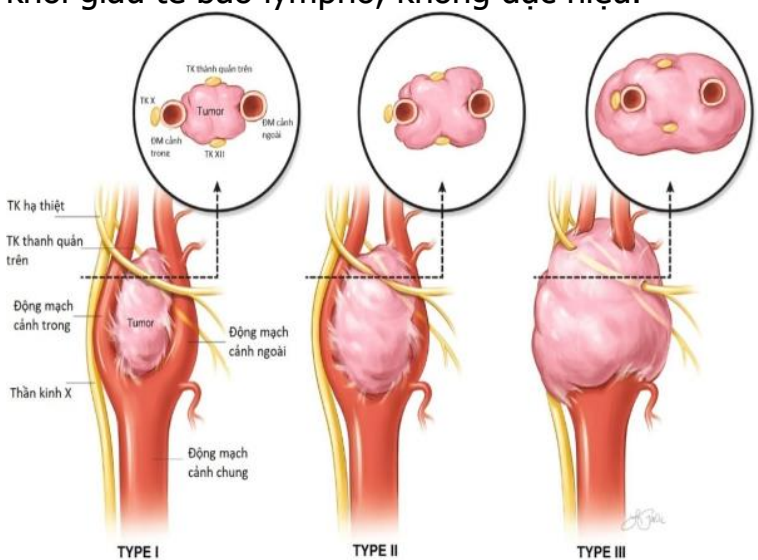

Hình 5: Phân loại u tiêu thể cảnh theo Shamblin [7]

Các khối u tiểu thể cảnh thường chỉ xuất hiện một bên, u tiến triển chậm nhưng có thể phát triển lớn gây chèn ép các cấu trúc xung quanh như mạch máu, thần kinh cũng như lan lên cao vùng nền sọ, gây ra các biến chứng và khó khăn cho việc điều trị. Vì vậy, khi được chẩn đoán thì việc điều trị càng sớm càng tốt mang lại hiệu quả cao và ít biến chứng cho bệnh nhân. Shamblin phân chia u tiểu thể cảnh làm 3 nhóm tùy theo mức độ xâm lấn của khối u (hình 5). Về điều trị, phẫu thuật là điều trị tối ưu nhất cho bệnh lý u tiểu thể cảnh. Trước mổ 24 giờ, can thiệp nút mạch làm tắc các nguồn cấp máu cho khối u là cần thiết, giúp han chế chảy máu trong mổ[7].Trong mổ, việc phẫu tích rõ và bảo tồn các cấu trúc thần kinh và mạch máu là quan trọng nhất, gồm các thần kinh thanh quản trên, thần kinh hạ thiệt (dây XII), thần kinh X. Vế thương tổn mạch máu, cố gắng bảo tồn tối đa hoặc mổ cắt mạch và tái lập toàn hoàn băng ghép mạch nhân tạo[7],[8].

Với bệnh nhân trên, chúng tôi chẩn đoán u tiểu thể cảnh, bệnh nhân được chỉ định nút mạch trước mổ, tuy nhiên do trong chụp xác định không có tăng sinh mạch nên bác sĩ can thiệp không thực hiện nút mạch như với một u tiểu thể cảnh kinh điển.Trước mổ, do khối u lên cao, việc hội chẩn với các chuyên khoa hàm mặt dự kiến mở xương hàm trong trường hợp khó là cần thiết và đã được chúng tôi thực hiện. Vùng Scarpa đùi cùng bên được để trong phẫu trường để lấy tĩnh mạch hiển lớn nếu cần. Trong mổ, phẫu thuật bộc lộ động mạch cảnh phía trung tâm dưới khối u khá dễ dàng, nhưng u xâm lấn mạnh lên cao, bao bọc quanh toàn bộ động mạch cảnh trong, cảnh ngoài nên việc phẫu tích về phía ngoại vi khó khăn. Các thần kinh $X, X I I$, thần kinh thanh quản trên được phẫu tích rõ ràng và được bảo tồn. Trong mổ khẳng định khối u xâm lấn chặt vào thành mạch máu không thể tách được, nên quyết đinh cắt bỏkhối u kèm theo chạc ba động mạch, tái lập tuần hoàn bằng cầu nối giữa động mạch cảnh chung-cảnh trong sử dụng mạch nhân tạo Goretex số 7(do tĩnh mạch hiển lớn tự thân lấy tại Scarpa phải kích thước quá nhỏ < 3mm, không dùng được), thắt động mạch cảnh ngoài do u xâm lấn tới chố chia của động mạch mặt.Sau mổ, bệnh nhân diễn biến ổn định, theo dõi không có biến chứng thần kinh. Bệnh nhân ra viện sau 1 tuần điều trị, và tiếp tục sử dụng thuốc chống đông máu, ức chễ miễn dịch sau mổ gồm aspirin $81 \mathrm{mg}$ ngày 1 uống 1 viên và prednisolon $4 \mathrm{mg}$, ngày uống 2 viên. Bệnh nhân khám lại sau một tháng, còn đau đầu nhẹ, ăn uống tốt, vết mổ khô, không sưng nề vùng góc hàm phải, siêu âm mạch cảnh trong thông tốt. Bệnh nhân tiếp tục được kê đơn sử dụng aspirin $81 \mathrm{mg}$ và prednisolon điêu trị tiếp.

\section{KẾT LUÂ̂N}

Viêm động mạch cảnh là một bệnh lý rất hiếm gặp, đã được mô tả trong y văn nhưng chủ yếu là báo cáo trường hợp lâm sàng với số lượng ca bệnh nhỏ lẻ. Bệnh không có triệu chứng đặc hiệu, chẩn đoán chủ yếu dựa vào triệu chứng đau khởi phát vùng cổ thường xảy ra một bên, và các dấu hiệu trên chẩn đoán hình ảnh. Bệnh cần được nghĩ đến nếu như dấu hiệu lâm sàng, cận lâm sàng không điển hình cho các bệnh lý khác (u tiểu thể cảnh, giả phình mạch cảnh do chấn thương...). Bênh vẩn chưa được hiểu rõ cơ chế cũng như chưa có thống nhất hướng dẫn điều trị. Chẩn đoán và điều trị bệnh vẫn còn là thách thức lớn vì là bệnh lý rất hiểm gặp và chưa có thống nhất trong chẩn đoán và điều trị.

\section{TÀI LIẸU THAM KHẢO}

1. Jennette, J.C., et al., 2012 revised International Chapel Hill Consensus Conference Nomenclature of Vasculitides. Arthritis Rheum, 2013. 65(1): p. 1-11. 
2. Fay, T.J.A.N.P., Atypical neuralgia. 1927. 18: p. 309-315.

3. Farage, L., et al., Idiopathic inflammatory pseudotumor of the carotid sheath.Arq Neuropsiquiatr, 2007. 65(4b): p. 1241-4.

4. The International Classification of Headache Disorders: 2nd edition. Cephalalgia, 2004. 24 Suppl 1: p. 9-160.

5. Burton, B.S., et al., MR Imaging of Patients with Carotidynia. 2000. 21(4): p. 766-769.

6. Lecler, A., et al., TIPIC Syndrome: Beyond the
Myth of Carotidynia, a New Distinct Unclassified Entity. 2017. 38(7): p. 1391-1398.

7. Robertson, V., et al., A Systematic Review and Meta-Analysis of the Presentation and Surgical Management of Patients With Carotid Body Tumours. Eur J Vasc Endovasc Surg, 2019. 57(4): p. 477-486.

8. Đoàn Quốc Hưng, Pham Tuấn Cảnh, Chử Vân Khánh. Chẩn đoán và điều trị u cuộn cảnh vùng đầu cổ. Tạp chí phẫu thuật tim mạch và lồng ngực Việt Nam 8/2017, 17: 33-38.

\section{TÁC DỤNG ĐÎ̀̀U TRI ĐAU THẮT LƯNG DO THOÁI HÓA CộT SỐNG BẰNG ĐIỆN CHÂM KẾT HỢP SIÊU ÂM ĐIỀU TRI}

\section{TÓM TẮT}

Mục tiêu: Đánh giá tác dụng giảm đau và cải thiện vận động cột sống của điện châm kết hợp siêu âm điều trị trên bệnh nhân đau thắt lưng do thoái hóa cột sống. Đối tượng và phương pháp: 60bệnh nhân tuổi trên 20được chẩn đoán đau thắt lưng do thoái hóa cột sống, không phân biệt giới tính, nghề nghiêp, tình nguyến tham gia nghiên cứu. Nhóm nghiển cứu điều trị bằng điện châm kết hợp siêu âm điêu trị, nhóm đối chứng điều trị bằng điện châm đơn thuần.So sánh kết quả trước vàsau điều trị. Kết quả: Điện châm kết hợp siêu âm điều trịcó hiệu quả tốt trong điều trị đau thắt lựng do thoái hóa cột sống, $80 \%$ đat kết quả tốt. Điểm VAS giảm từ 6,32 (điểm) trước điều trị xuống còn 0,70 (điểm) sau điều trị; độ giãn cột sống thắt lưng tăng từ $1,18(\mathrm{~cm})$ trước điều trị lên $3,83(\mathrm{~cm})$ sau điều trị;;tầm vận động cột sống thắt lưng cải thiện tốt hơn có ý nghĩa so với trước điêu trị và tốt hơn so với nhóm đối chứng. Kết luân: Điên châm kết hợp siêu âm điều trịhiệu quả tốt trong điểu trị đau thắt lưng do thoái hóa côtt sống.

Tư khóa: Điện châm, siêu âm điêuu trị, thoái hóa cột sống thắt lưng.

\section{SUMMARY \\ THE EFFECTS OF TREATMENTOF LOW BACK PAIN CAUSED BY DEGENERATIVE SPINEBY ELECTRIC ACUPUNCTURECOMBINED WITH ULTRASOUND TREATMENT}

Objective: To evaluate the pain-relieved effect and improvement in spine motor function of electric acupuncture combined with ultrasound treatmenton the low back pain caused by degenerative spine. Subjects and methods: 60 volunteered patients aged over 20 diagnosed with degenerative spondylosis

\footnotetext{
${ }^{1}$ Bệnh viện Châm cứu Trung ương,

2Viện Y học cổ truyền Quân đội

Chịu trách nhiệm chính: Nguyễn Đức Minh

Email: drminhchamcuu@gmail.com

Ngày nhận bài: 29/4/2021

Ngày phản biên khoa học: 25/5/2021

Ngày duyệt bài: 18/6/2021
}

\section{Nguyễn Đức Minh ${ }^{1}$, Nguyễn Vinh Quốc ${ }^{2}$}

of lumbar spine, regardless of gender or occupation, were participated in the study. Researchers combined using electric acupuncturewithultrasound treatment, while the control group was treated with electric acupuncture only. Comparing the results before and after treatment. Result: The low back pain caused by degenerative spine treating method by using the combination of electric acupuncturewithultrasound treatment worked efficiency, $80 \%$ rate of good results. The VAS score reduced from 6.32 (before the treatment) to 0.70 after the study; the lumbar spinal dilation increased from $1.18 \mathrm{~cm}$ to $3.83 \mathrm{~cm}$ after the treatment; the lumbar spine movementimproved better than before treatment and better than control group, difference was statistically significant. Conclusion: The treating method usingelectric acupuncture withultrasound treatmentis effective in treating low back pain caused by degenerative spine.

Keywords: Electric acupuncture, ultrasound treatment, degenerative lumbar spine

\section{I. ĐĂT VẤN ĐỀ}

Đau thắt lưng do thoái hóa cột sống (THCS) là bệnh lý thường gặp và chiếm tỷ lệ caotrong nhóm các bệnh lý xương khớpvới biểu hiện lâm sàng cơ bản là đau. Bệnh ảnh hưởng tới năng suất lao động, chất lượng cuộc sống và sinh hoạt của người bệnh [1]. Đau thắt lưng do THCS không điêu trị kịp thời hoặc điêuu trị khôngđúng phương pháp có thể để lại những hậu quả nặng nề, gây gánh nặng cho bản thân người bệnh, cho gia đình và xã hội [1],[2]. Do vậy điêu trị hiệu quả bệnh lý này đang là mối quan tâm nghiên cứu của các thây thuốc.

Theo $\mathrm{Y}$ học cổ truyên (YHCT), THCS thắt lưng được biết tới với bệnh danh Yêu thống. Điều trị bệnh lý này có rất nhiều phương pháp mang lại hiệu quả tốt trong đó có các phương pháp điều trị không dùng thuốc[3],[4]...

Điện châm là phương pháp điêu trị có tác dụng giảm đau, giãn cơ thường được các thây thuốc YHCT áp dụng trong điều trị bệnh lý cơ 